\title{
Cephalic Radiation and Retinal Vasculopathy
}

\author{
W. M. K. AMOAKU and D. B. ARCHER \\ Belfast
}

\begin{abstract}
Summary
The retinal vascular complications in patients receiving cephalic radiation for various lesions over a ten year period were reviewed. The incidence of retinopathy was $17 \%$ overall, but increased with proximity of the treatment site to the eye, being highest in irradiation of the eye/orbit $(85.7 \%)$, paranasal sinuses $(45.4 \%)$ and nasopharynx $(36.4 \%)$. The risk of retinopathy increased significantly when the total dose of radiation exceeded 3000 cGy.

The occlusive vasculopathy and capillary incompetence which were the most clinically important features of radiation retinopathy may be exacerbated by pre-existing diabetes.

Radiation retinopathy has a long latency and may not be clinically detectable for eight years or more. Long follow-up times with sequential fundoscopy should increase early detection and optimise treatment with laser photocoagulation.
\end{abstract}

The eye and ocular adnexae are vulnerable to ionising radiation although the susceptibility of the individual tissues shows great variation. ${ }^{1}$

Radiation damage to ocular tissues is' also related to the cumulative dose of radiation, ${ }^{2-4}$ the dose fractionation ${ }^{5,6}$ and the energy of the radiation beam. ${ }^{3,7}$ The eye may sustain direct radiation damage during radiotherapy for ocular and adnexal tumours or receive indirect injury from gratuitous radiation during the treatment of more remote tumours of the head and neck. The extent of ocular damage from gratuitous radiation can be limited by prophylactic shielding, the use of multiple therapeutic portals and the employment of coherent radiation sources with low scatter characteristics. Nevertheless despite improvements in radiotherapeutic methods and shielding techniques, it is often difficult for the radiotherapist to treat adequately many deep-seated cephalic tumours without irradiating the posterior orbit and eye. ${ }^{4}$

There have been several reports of ocular complications following radiotherapy to tumours of the nasopharynx,${ }^{8-10}$ the paranasal sinuses $^{9,11,12}$ and the central nervous system. ${ }^{13-15}$ Other workers have recorded ocular pathology secondary to orbital and ocular radiation particularly in cases of orbital lymphoma, ${ }^{16,17}$ retinoblastoma ${ }^{16,18}$ and choroidal melanoma. ${ }^{16}$ No study, as yet, has determined the relative risks of developing radiational retinopathy with regard to the site of primary treatment and to determine this we conducted a retrospective study of all patients in Northern Ireland receiving cephalic radiation over a period of ten years.

\section{Materials and Methods}

An initial pool of subjects was drawn from patients attending the Northern Ireland

*This investigation as supported by a grant from the British Council for Prevention of Blindness.

Correspondence to: Department of Ophthalmology, The Queen's University of Belfast, Eye and Ear Clinic, Royal Victoria Hospital, Belfast BT12 6BA. 
Table I Cephalic Radiation and Retinopathy-Incidence

\begin{tabular}{lcccc}
\hline Site of irradiation & $\begin{array}{c}\text { Total no } \\
\text { of patients }\end{array}$ & $\begin{array}{c}\text { No of patients } \\
\text { reviewed }\end{array}$ & $\begin{array}{c}\text { No of patients } \\
\text { with retinopathy }\end{array}$ & $\begin{array}{c}\text { \% incidence } \\
\text { of retinopathy }\end{array}$ \\
\hline Eye orbit & 7 & 7 & 6 & 85.7 \\
Nasal cavities & 17 & 11 & 5 & 45.4 \\
$\quad$ paranasal sinuses & 13 & 11 & 4 & 36.4 \\
Nasopharynx & 47 & 32 & 1 & 3.1 \\
Brain & 9 & 7 & 0 & 0 \\
Middle/ext ear & 25 & 15 & 0 & 0 \\
Mouth & 20 & 10 & 0 & 0 \\
Salivary glands & 2 & 1 & 0 & 17 \\
Skull bone & 140 & 94 & 16 & 0 \\
Total & & & & \\
\hline
\end{tabular}

Radiotherapy centre, Belvoir Park Hospital, Belfast for radiotherapy of various head and neck lesions between January 1975 and December 1984. The radiation treatment schedules of all patients involved were examined, and the details of the type of radiation, total dose, fractionate, duration of treatment and portals used were obtained from the case notes. Any use of adjunctive chemotherapy was also noted.

All surviving patients in this group were invited to attend the Eye and Ear Clinic, Royal Victoria Hospital where they had ocular biomicroscopy, fundoscopy, ocular electrophysiology and measurement of visual function. Fundus photography and fluorescein angiography were carried out where retinopathy was suspected or present. Fifteen patients who had significant ocular radiation but no retinal vasculopathy had fluorescein angiography to determine whether subtle changes had occurred at the level of the retinal pigment epithelium. Patients with radiation vasculopathy had a full systemic examination and laboratory investigations to exclude diabetes, hypertension, collagen disease or other associated vasculopathy. Patients, who were too ill to attend or had emigrated were excluded from the study.

\section{Results}

Ninety four patients, out of a possible total of $140,(70 \%)$ attended the Eye clinic for assessment. The age range was $4 \frac{1}{2}$ years to 86 years (mean 49.5). There were 52 males and 42 females.

\section{Incidence}

Sixteen patients were found to have radiation vasculopathy and retinal pigment epithelial changes $(17 \%)$, eleven males and five females. The incidence of radiation retinopathy with respect to the site of primary pathology (Table I) was highest for orbital and eye radiation. Radiation of the nasal cavities, paranasal sinuses and nasopharynx also had a high incidence of post treatment retinopathy. The only patient receiving intracranial radiation to develop retinopathy was also diabetic and had received concurrent chemotherapy 1-(2-chlorethyl)-3-cyclohexyl1-nitrosurea (CCNU). Radiotherapy to cephalic tumours more remote from the eye, eg ear, mouth and salivary glands carried no risk of retinopathy within the follow-up time of this study.

\section{Distribution}

Radiation retinopathy was unilateral in ten patients and bilateral in six patients (Table II). Patients developing retinopathy subsequent to treatment of nasopharyngeal tumours, had involvement of both eyes and in three of four patients in this group the retinopathy was similar both in terms of severity and distribution. Patients receiving treatment for lesions of the eye, orbit or maxillary

Table II Cephalic radiation and retinopathy laterality

\begin{tabular}{lcc}
\hline Site of irradiation & Unilateral & Bilateral \\
\hline Eye/orbit & 6 & 0 \\
Nasal cavities & & \\
$\quad$ paranasal sinuses & 4 & 1 \\
Nasopharynx & 0 & 4 \\
Brain & 0 & 1 \\
Others & 0 & 0 \\
\hline
\end{tabular}




\begin{tabular}{|c|c|c|c|c|c|c|c|}
\hline Patient & $\begin{array}{l}\text { Age } \\
\text { (yrs) }\end{array}$ & Diagnosis & $\begin{array}{l}\text { Radiation dosel } \\
\text { fractions }\end{array}$ & Retinopathy & $\begin{array}{l}\text { Other ocular } \\
\text { complications }\end{array}$ & $\begin{array}{l}\text { Interval } \\
\text { to initial } \\
\text { exam (and } \\
\text { final exam) }\end{array}$ & $\begin{array}{l}\text { Final } \\
\text { visual } \\
\text { acuity }\end{array}$ \\
\hline 1 & 65 & $\begin{array}{l}\text { Lymphocytic } \\
\text { Lymphoma (R) } \\
\text { Medial Orbit } \\
\text { (subsequently became } \\
\text { diabetic) }\end{array}$ & $3500 \mathrm{cGy} / 19 f$ & $\begin{array}{l}\text { (R) Macular } \\
\text { Oedema } \\
\text { Exudation }\end{array}$ & $\begin{array}{l}\text { (R) Conjunctival } \\
\text { Leukoplakia (Medial) } \\
(\mathrm{R}) \text { Cataract } \rightarrow \text { ECCE } \\
+ \text { IOL }\end{array}$ & $\begin{array}{l}5.5 \mathrm{yrs} \\
(8.5 \mathrm{yrs})\end{array}$ & $\begin{array}{c}R-6 / 18 \\
+3 \\
L-6 / 6\end{array}$ \\
\hline 2 & 15 & $\begin{array}{l}\text { Rhabdomyosarcoma } \\
\text { (R) Orbit }\end{array}$ & $\begin{array}{l}4800 \text { cGy/20f } \\
\text { (+ chemotherapy) }\end{array}$ & $\begin{array}{l}\text { (R) Macular } \\
\text { Exudation } \\
\text { Telangiectasia, } \\
\text { Microaneurysms }\end{array}$ & $\begin{array}{l}(\mathrm{R}) \text { Cataract } \rightarrow \\
\text { Lensectomy }\end{array}$ & $\begin{array}{c}5 \text { yrs } \\
(11 \text { yrs })\end{array}$ & $\begin{array}{l}R-6 / 60 \\
L-6 / 6\end{array}$ \\
\hline 3 & 45 & $\begin{array}{l}\text { Lacrimal Sac } \\
\text { Lymphoma (L) }\end{array}$ & $\begin{array}{l}3750 \mathrm{cGy} / 20 \mathrm{f} \\
\text { (+ chemotherapy) }\end{array}$ & $\begin{array}{l}\text { (L) Macular Pigment } \\
\text { Epith. Changes } \\
\text { Dilated Macular } \\
\text { Capillaries } \\
\text { Microaneurysms }\end{array}$ & $\begin{array}{l}\text { (L) Cataract } \rightarrow \\
\mathrm{ECCE}+\mathrm{IOL}\end{array}$ & $\begin{array}{l}4 \text { yrs } \\
(6 \text { yrs })\end{array}$ & $\begin{array}{l}\mathrm{R}-6 / 6 \\
\mathrm{~L}-6 / 9\end{array}$ \\
\hline 4 & 70 & $\begin{array}{l}\text { Lymphoma (L) } \\
\text { Orbit }\end{array}$ & $\begin{array}{l}750 \mathrm{cGy} / 3 \mathrm{f}+ \\
2667 \mathrm{cGy} / 12 \mathrm{f} \\
\text { (+ chemotherapy) }\end{array}$ & $\begin{array}{l}\text { (L) Haemorrhages } \\
\text { Microinfarcts sup. \& } \\
\text { Nasal Retina }\end{array}$ & - & $\begin{array}{l}7 \text { yrs } \\
\text { (8 yrs) }\end{array}$ & $\begin{array}{c}\mathrm{R}-6 / 12 \\
\text { (amblyopia) } \\
\mathrm{L}-6 / 6\end{array}$ \\
\hline 5 & 15 & $\begin{array}{l}\text { Rhabdomyosarcoma } \\
\text { (R) Orbit }\end{array}$ & $\begin{array}{l}5000 \mathrm{cGy} / 25 \mathrm{f} \\
\text { (+ chemotherapy) }\end{array}$ & $\begin{array}{l}\text { (R) Presumed } \\
\text { Retinopathy (no } \\
\text { fundus view) }\end{array}$ & $\begin{array}{l}\text { (R) Keratoconjunc- } \\
\text { tivitis, Trichiasis, } \\
\text { corneal vasculari- } \\
\text { cation, NVG, Cataract }\end{array}$ & $\begin{array}{l}2.2 \mathrm{yrs} \\
(5 \mathrm{yrs})\end{array}$ & $\begin{array}{l}\text { R-PL } \\
\text { L-6/6 }\end{array}$ \\
\hline 6 & 59 & $\begin{array}{l}\text { Squamous cell } \\
\text { Carcinoma } \\
\text { Lateral } \\
\text { Conjunctiva (R) }\end{array}$ & $4316 \mathrm{cGy} / 20 \mathrm{f}$ & $\begin{array}{l}\text { (R) Presumed } \\
\text { Retinopathy (no } \\
\text { fundus view) }\end{array}$ & $\begin{array}{l}\text { (R) Lid Telangiectasia } \\
\text { Corneal vasculari- } \\
\text { zation, Rubeosis Iridis } \\
\text { Cataract }\end{array}$ & $\begin{array}{l}3.5 \text { yrs } \\
(6 \mathrm{yrs})\end{array}$ & $\begin{array}{l}\text { R-PL } \\
\mathrm{L}-6 / 6\end{array}$ \\
\hline 7 & 68 & $\begin{array}{l}\text { Anaplastic } \\
\text { Carcinoma } \\
\text { Nasopharynx }\end{array}$ & $5000 \mathrm{cGy} / 25 \mathrm{f}$ & $\begin{array}{l}\text { Bilat. Macular } \\
\text { Microaneurysms } \\
\text { \& Macular } \\
\text { Exudation (R) }\end{array}$ & $\begin{array}{l}\text { Posterior subcapsular } \\
\text { cataract }\end{array}$ & $\begin{array}{c}8 \mathrm{yrs} \\
(11 \mathrm{yrs})\end{array}$ & $\begin{array}{l}\mathrm{R}-6 / 18 \\
\mathrm{~L}-6 / 6\end{array}$ \\
\hline 8 & 35 & $\begin{array}{l}\text { Carcinoma } \\
\text { Nasopharynx }\end{array}$ & $5250 \mathrm{cGy} / 25 \mathrm{f}$ & $\begin{array}{l}\text { Bilat. Macular } \\
\text { Microaneurysms }\end{array}$ & 一 & $\begin{array}{l}4.8 \mathrm{yrs} \\
(8 \mathrm{yrs})\end{array}$ & $\begin{array}{l}\mathrm{R}-6 / 6 \\
\mathrm{~L}-6 / 9\end{array}$ \\
\hline 9 & 62 & $\begin{array}{l}\text { Carcinoma } \\
\text { Nasopharynx } \\
\text { (+ diabetes) }\end{array}$ & $\begin{array}{l}4424 \text { cGy/24f } \\
\text { (+ chemotherapy) }\end{array}$ & $\begin{array}{l}\text { Bilat. Post. Pole } \\
\text { microaneurysms } \\
\text { Haemorrhages } \\
\text { Exudates especially } \\
\text { inferonasally (L) }\end{array}$ & - & $\begin{array}{l}2.8 \mathrm{yrs} \\
(4.5 \mathrm{yrs})\end{array}$ & $\begin{array}{l}R-6 / 6 \\
L-6 / 6\end{array}$ \\
\hline 10 & 48 & $\begin{array}{l}\text { Adenocystic } \\
\text { Carcinoma } \\
\text { Nasopharynx }\end{array}$ & $5250 \mathrm{cGy} / 25 \mathrm{f}$ & $\begin{array}{l}\text { Bilat. Macular Micro- } \\
\text { aneurysms, Exudates } \\
\text { Vascular closure. } \\
\text { Irregular arterioles } \\
\text { with IRMA's }\end{array}$ & Bilat. Optic Atrophy & $\begin{array}{c}3 \mathrm{yrs} \\
(11.5 \mathrm{yrs})\end{array}$ & $\begin{array}{l}R-6 / 60 \\
L-6 / 9\end{array}$ \\
\hline 11 & 42 & $\begin{array}{l}\text { Recurrent } \\
\text { Melanoma (L) } \\
\text { Nasal Mucosa } \\
\text { (+ Bilat. Breast } \\
\text { Carcinoma) }\end{array}$ & $\begin{array}{l}5000 \mathrm{cGy} / 25 f \\
\text { (+ chemotherapy) }\end{array}$ & $\begin{array}{l}\text { L Macular micro- } \\
\text { aneurysm. Focal } \\
\text { Vascular constriction } \\
\text { neovascularisation } \\
\text { inferior retina } \\
\text { preretinal } \\
\text { haemorrhage. }\end{array}$ & Cataract (Sector) & 5 yrs & $\begin{array}{r}\mathrm{R}-6 / 6 \\
\mathrm{~L}-6 / 12\end{array}$ \\
\hline 12 & 50 & $\begin{array}{l}\text { Adenocarcinoma } \\
\text { (L) Ethmoid \& } \\
\text { (L) Nostril }\end{array}$ & $5000 \mathrm{cGy} / 25 \mathrm{f}$ & $\begin{array}{l}\text { Bilateral } \\
\text { (R) nerve fibre } \\
\text { Haemorrhages } \\
\text { (L) Circinate macul- } \\
\text { opathy arteriolar } \\
\text { constriction } \\
\text { haemorrhages }\end{array}$ & $\begin{array}{l}\text { Temporal Disc } \\
\text { Pallor (L) } \\
\text { Cataract (L) }\end{array}$ & $\begin{array}{c}1 \mathrm{yr} \\
(6.5 \mathrm{yrs})\end{array}$ & $\begin{array}{c}R-6 / 6 \\
L-6 / 18\end{array}$ \\
\hline 13 & 62 & $\begin{array}{l}\text { Squamous cell } \\
\text { Carcinoma } \\
\text { (R) Maxillary Antrum } \\
\text { (R) Ethmoid }\end{array}$ & $4350 \mathrm{cGy} / 20 \mathrm{f}$ & $\begin{array}{l}\mathrm{R} \text { macular } \\
\text { Haemorrhages, } \\
\text { microaneurysms } \\
\text { Telangiectasia }\end{array}$ & $\begin{array}{l}\text { (R) Cataract } \\
\text { ECCE \& IOL }\end{array}$ & $\begin{array}{l}8.5 \text { yrs } \\
(11 \text { yrs })\end{array}$ & $\begin{array}{l}\mathrm{R}-6 / 9 \\
\mathrm{~L}-6 / 5\end{array}$ \\
\hline 14 & 69 & $\begin{array}{l}\text { Squamous cell } \\
\text { Carcinoma } \\
\text { (L) Maxillary Antrum }\end{array}$ & $5548 \mathrm{cGy} / 19 f$ & $\begin{array}{l}\text { (L) Presumed } \\
\text { Retinopathy (no } \\
\text { fundus view) }\end{array}$ & $\begin{array}{l}\text { (L) Absolute NVG } \\
\text { Cataract, Corneal } \\
\text { vascularization }\end{array}$ & $3.75 \mathrm{yrs}$ & $\begin{array}{r}\mathrm{R}-6 / 6 \\
\mathrm{~L}-\mathrm{NPL}\end{array}$ \\
\hline 15 & 70 & $\begin{array}{l}\text { Squamous cell } \\
\text { Carcinoma } \\
\text { (L) Antrum }\end{array}$ & $5460 \mathrm{cGy} / 26 \mathrm{f}$ & $\begin{array}{l}\text { (L) Macular micro- } \\
\text { aneurysms, vascular } \\
\text { exudates and } \\
\text { haemorrhages }\end{array}$ & $\begin{array}{l}\text { (L) Cataract } \rightarrow \\
\text { ECCE \& IOL }\end{array}$ & 6.6 yrs & $\begin{array}{l}\mathrm{R}-6 / 18 \\
\text { senile } \\
\text { cataract } \\
\mathrm{L}-6 / 9\end{array}$ \\
\hline 16 & 38 & $\begin{array}{l}\text { Parieto-Temporal } \\
\text { Astrocytoma (R) } \\
\text { (+ diabetes) }\end{array}$ & $\begin{array}{l}5000 \mathrm{cGy} / 20 \mathrm{f} \\
\text { (+ chemotherapy) }\end{array}$ & $\begin{array}{l}\text { Bilat. Superior retinal } \\
\text { micro-infarction and } \\
\text { haemorrhages }\end{array}$ & 一 & 2 yrs & $\begin{array}{l}R-6 / 6 \\
L-6 / 6\end{array}$ \\
\hline
\end{tabular}

Note: $\mathrm{ECCE}+\mathrm{IOL}=$ Extracapsular cataract and intraocular lens implantation

NVG = Neovascular Glaucoma

IRMA = Intraretinal microvascular abnormalities 


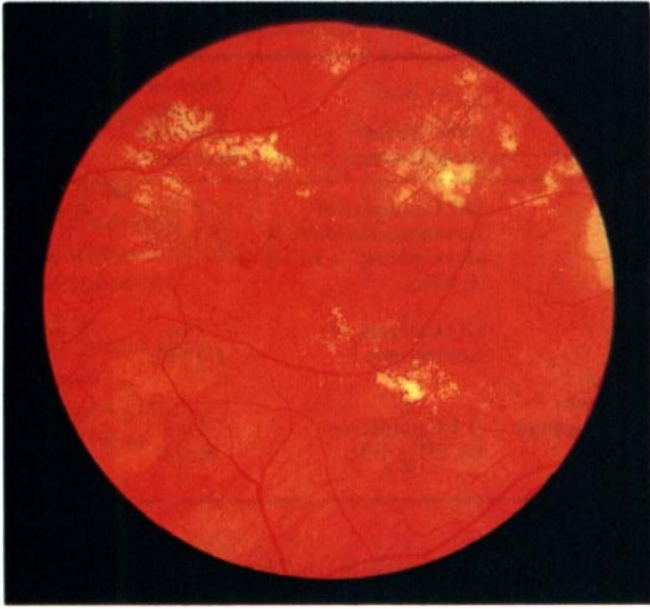

Fig. 1a Fundus photograph right macula of Patient 10, five years after receiving 5250 cGy for $a$ nasopharyngeal carcinoma. There are macular microaneurysms, dilated capillaries, hard exudates and oedema. Discrete retinal pigment epithelial degenerative changes are present at the right foveola.

antrum had only involvement of the ipsilateral eye.

\section{Morphological Features}

The radiation vasculopathy consisted mostly of microaneurysms and fusiform and saccular dilatations of the retinal microvasculature (Table III). These alterations were largely concentrated in the macular and peripapillary regions (Fig. 1). Two patients, however, who had eccentric radiation of the eyes (Patients 11 and 16) developed asymmetrical retinopathy which corresponded with the field of radiation.

Other retinopathic changes included intraretinal haemorrhages, hard and soft exudates and intraretinal microvascular abnormalities. Striking calibre changes were also noted in arterioles and veins particularly beading and sheathing (Fig. 1). One patient has extensive inner retinal ischaemia, preretinal neovascularisation and preretinal haemorrhage. Three patients had optic atrophy attributable to radiation, however, a number of patients with intracranial neoplasms had optic atrophy that was considered primary to the disease process.

Of the 94 study patients, five had evidence of systemic vascular disease, three with diabetes and two were receiving treatment for hypertension at the time of radiotherapy. Two of the three diabetic patients developed evidence of radiation retinopathy. One diabetic, noted above, had bilateral asymmetrical retinopathy corresponding with the field of radiation eccentric to the eye. A second patient diagnosed diabetic one year prior to the commencement of radiotherapy for a nasopharyngeal tumour developed bilateral retinopathic changes three years after treatment. A third diabetic patient receiving radiotherapy for nasopharyngeal cancer did not develop any retinopathy. This patient, however, only survived two years following treatment for the tumour. A further patient was diagnosed diabetic six years following radiotherapy for a right orbital lymphoma. This individual was found to have radiation vasculopathy in the eye receiving radiotherapy one year prior to the diagnosis of diabetes. None of the patients with systemic hypertension developed retinopathy following radiotherapy.

Three patients whose fundi could not be inspected because of medial opacities were presumed to have radiational retinopathy. All three patients had advanced rubeosis iridis and neovascular glaucoma and had received high doses of radiation to the unprotected eye (Table III).

\section{Fluorescein Angiography}

In radiation retinopathy fluorescein angiography demonstrated striking and character-

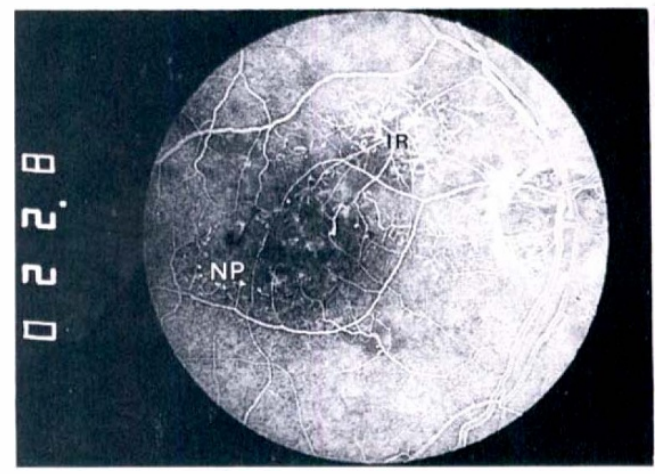

Fig. 1b Mid-venous phase fluorescein angiogram of fundus shown in Fig. 1a, displays grossly dilated and incompetent capillaries, microaneurysms and intraretinal microvascular abnormalities (IR). Extensive areas of capillary non-perfusion are present in the temporal and superior macular (NP). 


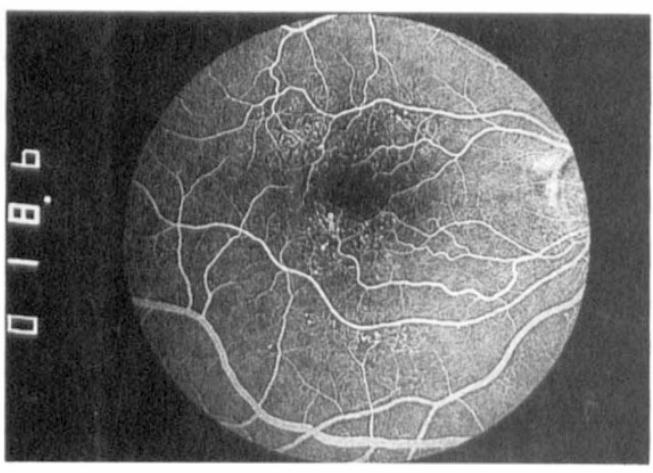

Fig. 2a Venous phase angiogram of Patient 7; eight years after receiving 5000 cGy for a nasopharyngeal carcinoma. The dilated macular microvasculature has numerous microaneurysms but is relatively well perfused.

istic changes in the architecture of the retinal microvasculature with varying degrees of capillary incompetence and closure. In early disease the affected capillary bed was grossly dilated and interspersed with numerous microaneurysms (Fig. 2). Deformed capillaries stained vividly with dye in the later phase of angiography but often remained relatively competent.

As the retinopathy developed the microvasculature became incompetent with evidence of focal and generalised macular oedema (Fig. 1a,b)

In more advanced disease capillary dropout was a feature (Figs. 1a,b) and in some patients focal or generalised areas of inner retinal ischaemia were identified (Fig. 3).

\section{Chemotherapy}

Eleven of the 94 study patients received adjunctive chemotherapy with various agents (tamoxifen, vincristine, actinomycin, 5-fluorouracil and 1-(2-chlorethyl)-3-cyclohexly-1-nitrosurea). Seven of the above 11 patients who had received chemotherapy developed radiation vasculopathy (Table I).

\section{Anterior Segment Changes}

Anterior segment complications of radiation included neovascular glaucoma (NVG), cataract, corneal vascularisation, corneal oedema, superficial punctate keratitis (SPK), keratoconjunctivitis, conjunctival leukoplakia, madarosis, trichiasis and eyelid telangiec-

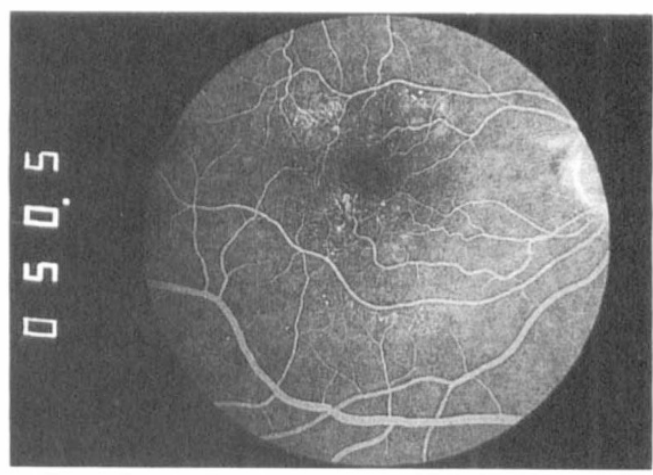

Fig. 2b Residual angiogram of macular area shown in Fig. 2a. Many microaneurysms and dilated capillaries stain with dye, however, most vessels are competent (visual acuity 6/6).

tasia. Anterior segment complications occurred predominantly in patients treated for eye and orbital tumours and in those receiving therapy for tumours of the nose and paranasal sinuses. Anterior segment complications were absent in patients receiving treatment for nasopharyngeal and intracranial tumours.

\section{Visual Acuity}

Visual acuity was assessed in 22 eyes (16 patients) with identifiable retinopathy (Tables III and IV). Thirteen eyes with mild retinopathy, ie microaneurysms and dilated capillaries had a corrected visual acuity of $6 / 9$ or better. Three of these eyes had extracapsular cataract extraction (ECCE) and intraocular

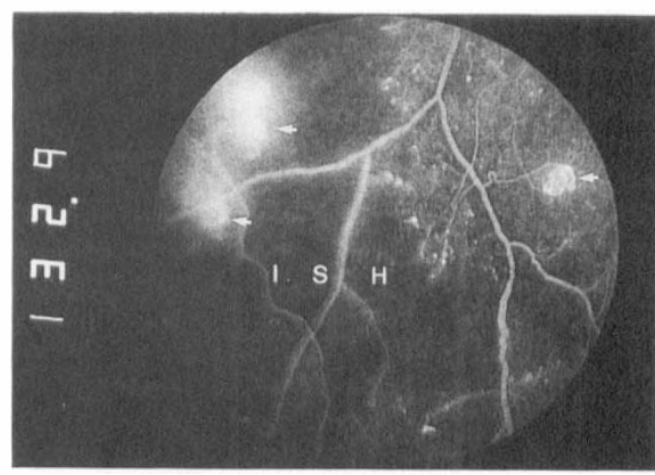

Fig. 3 Late phase venous angiogram of inferior left fundus Patient 11, five years after receiving 5000 cGy for a nasal melanoma. There is widespread inferior inner retinal ischaemia (ISH) and preretinal neovascularisation (arrows). Residual perfused retina has numerous microaneurysms. 
Table IV Cephalic radiation-retinopathy visual acuity (16 patients-22 eyes)

\begin{tabular}{clllc}
\hline $\begin{array}{c}\text { No. of } \\
\text { Eyes (22) }\end{array}$ & Retinopathy & Anterior segment & Visual acuity & $\begin{array}{c}\text { Time interval from } \\
\text { irradiation (yrs) }\end{array}$ \\
\hline 13 & Mild retinopathy & 3 ECCE/IOL & $6 / 9$ or better & $2.5-11(7)$ \\
2 & Mild/moderate & Cataract & $6 / 12-6 / 18$ & $5-6(5.5)$ \\
& retinopathy & 1 ECCE/IOL & $6 / 18-6 / 60$ & \\
4 & Severe retinopathy & $\begin{array}{l}\text { 1 Lensectomy } \\
\text { Neovasc }\end{array}$ & PL-NPL & $8-11(10)$ \\
& Presumed retinopathy & & $3.5-5(4)$ \\
& & $\begin{array}{l}\text { Geratopathy } \\
\text { Cataract }\end{array}$ & & \\
\hline
\end{tabular}

lens implantation (IOL). The time from radiotherapy to final measurement of visual acuity was 2.5 to eleven years (mean seven years).

Two eyes with moderate retinopathy, ie microaneurysms, dilated capillaries and retinal ischaemia, and evidence of macular oedema in one eye (Patient 12), had corrected visual acuities of $6 / 18$ and $6 / 12$. In one patient (Patient 11) cataract formation was judged to have contributed significantly to the visual decline. The time from radiotherapy to assessment of visual acuity in these patients was five and six years.

Four eyes with severe retinopathy, ie advanced and widespread microvascular changes, inner retinal ischaemia and maculopathy had a corrected visual acuity between $6 / 18$ and $6 / 60$, with a follow-up period of eight to ten years. Two patients in this group had laser photocoagulation for macular oedema.

Three eyes with bare perception or no perception of light were presumed to have advanced ischaemic retinopathy on the basis of having advanced rubeosis iridis and neovascular glaucoma. All these eyes also had entrenched keratopathy and advanced cataract.

\section{Natural Course}

Because of the retrospective nature of the study it was not possible to calculate the latency of microangiopathy with any degree of accuracy. The interval between radiation treatment and the detection of radiational retinopathy in this series varied between one and 8.5 years (mean 4.7 years). Eight of the 16 patients were followed up for a period of two to four years. One patient with microaneu- rysms showed no significant change over a period of three years. A further patient with moderately advanced radiation retinopathy showed some slight improvement over a period of five years. The remaining six patients all showed microangiopathic deterioration with capillary dropout, increase in the number of microvascular abnormalities and intensification of macular oedema.

\section{Treatment}

Two patients (Patients 1 and 7) in the present series received laser photocoagulation for radiation retinopathy. Both patients developed exudative maculopathy associated with deterioration of vision. Focal argon laser photocoagulation was carried out to areas having the highest concentration of incompetent capillaries. Visual acuity in one patient improved from $6 / 36$ to $6 / 18$ within three months of therapy with gradual absorption of macular fluid(Fig. 4). Vision has been maintained at this level for eight months. The second patient has only had recent therapy and is still under follow-up. One patient in the series with proliferative retinopathy and preretinal haemorrhage was advised to have therapy; however, treatment was declined.

\section{Discussion}

Radiation retinopathy is a well documented complication of ocular and orbital radiation and although the various elements of the retina show a spectrum of sensitivity to radiation the cells of the retinal microvasculature are among the most radiosensitive. Radiation injury to the retinal vascular cells leads to vessel closure $e^{4,8,16}$ and an ischaemic retinopathy which has more disastrous con- 


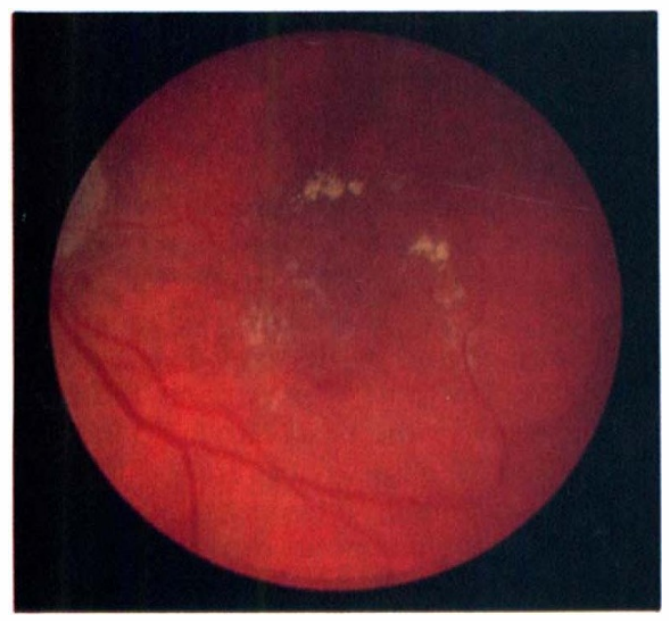

Fig. 4a Fundus photograph right macula of Patient 1, who received $3500 c G y$ for lymphoma of the right orbit. There is oedema and exudation superior to the right macula (visual acuity 6/36).

sequences on the retinal neuropile than the direct effects of radiation. Although the total dose of radiation to the retina is probably the most important factor in determining whether retinopathy develops other therapeutic parameters are also important, particularly the size of the fractionation dose $, 5,6,10,11$ the timing of treatment and the energy of the radiation source. ${ }^{3,7}$ Other factors which may influence the development of retinopathy are the concurrent use of chemotherapy ${ }^{12,19}$ and systemic conditions such as diabetes, hypertension and collagen diseases. ${ }^{10,16,20}$

The exact amount of radiation required to precipitate retinopathy is not known although several studies of orbital radiation for ophthalmic Graves' disease indicate that 2000 cGy of radiotherapy can be tolerated without the development of retinopathy. ${ }^{21-23}$

Bessel et al. ${ }^{17}$ found no retinopathy in 73 patients receiving 3000-4000 cGy for orbital lymphomata although Mewis et al. ${ }^{24}$ did find retinopathy in three patients given 2500-3000 cGy for choroidal metastasis. These data are in accord with the present study which demonstrates retinopathy in all patients receiving over $3400 \mathrm{cGy}$ to the orbit. It therefore seems likely that the threshold dose for radiation damage to the retinal vasculature lies between 2500 and 3000 cGy when X-ray or gamma sources are employed.
In the present study the incidence of radiation retinopathy was highest in those patients receiving radiation directly to the eye and orbit and those sites in close proximity to the orbit where shielding is not possible, ie the paranasal sinuses and the nasopharynx. The incidence of retinopathy following irradiation of the paranasal sinuses is lower than that reported by Medina et al., however, these workers used significantly higher doses of radiation and the eye and orbit were included in the field of irradiation. The occurrence of retinopathy following irradiation of the nasopharynx was typically lower than for the paranasal sinuses and the figure of $36.4 \%$ is identical to that reported by Medina et al. It is obvious that the relationship of radiation retinopathy to the site of cephalic radiotherapy is based on the proximity of the target site to the eye and hence the amount of radiation received by the retina.

There are considerable difficulties in determining the exact amount of radiation received by the retina in patients having treatment for tumours of the paranasal sinuses, nasopharynx and cerebrum. Antral irradiation delivers a significant dose to the retina and optic nerve because the roof of the antrum rises postero-medially (to about the level of the cornea). ${ }^{4,25}$ Furthermore, the orbit may be involved by extension of the tumour thus necessitating inclusion of the orbit in the field

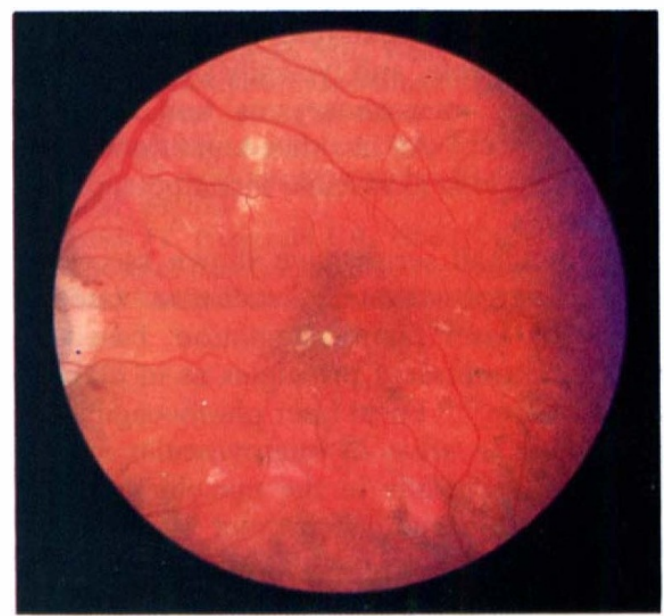

Fig. 4b Fundus photograph right macular shown Fig. $4 a$, three months post laser photocoagulation. Macular oedema has diminished and hard exudates partially absorbed (visual acuity 6/18). 
of treatment. ${ }^{4,9}$ Similar considerations would apply to treatment of the ethmoid sinuses and nasopharynx since direct extension may occur to involve the orbit and/or the sphenoid bone. ${ }^{8,9}$

While treatment of malignant disease should not be compromised to avoid ocular complications the extent of disease should be evaluated by CT scan and in the absence of orbital extension the dose of radiation to the orbit could be significantly controlled through individualised planning of the treatment fields and the use of highly collimated beams.

There have been anecdotal reports that pre-existing diabetes lowers the threshold at which radiation retinopathy occurs. ${ }^{16,20}$. This is not surprising since both diseases are occlusive microangiopathies. Becuase of this synergism it is particularly important that radiation doses in diabetics should be closely monitored and possibly reduced.

Radiation retinopathy has a variable and often delayed onset $t^{3,4,8,10}$ which in the present study was found to be as long as eight years. It is thus important to institute adequate follow-up for patients receiving cephalic radiation.

Radiation vasculopathy has been known to take a variable course. Although vascular remodelling was reported by Bagan et al. ${ }^{13}$ and Noble $e t$ al. ${ }^{26}$ there is a general tendency for the vasculopathy to progress. ${ }^{8,9,16}$ The macular microvasculature seems to be the most vulnerable, and typically shows sac-like dilatations, microaneurysms and capillary fallout. ${ }^{4,8,16,27,28}$ As in other conditions these alterations lead to vascular incompetence and leakage.

Many small series have shown successful treatment of advancing radiation vasculopathy by laser photocoagulation, based on the same treatment principles as in diabetic retinopathy. ${ }^{29,30}$ Focal laser photocoagulation is applied to areas of microvascular incompetence, especially in the macular area..$^{27-29}$ Significant macular ischaemia is a contraindication to photocoagulation, as it is in diabetic maculopathy. Neovascularisation of the retina or optic disc is treated by laser photocoagulation (either sector or panretinal) to obliterate the ischaemic retina. ${ }^{8,29-31}$ As in diabetes vitrectomy is indicated where there is persistent vitreous haemorrhage or traction retinal detachment which threatens the macular. ${ }^{29}$

\section{Conclusions}

Retinal vasculopathy after cephalic radiation is more common than previously thought. Patients receiving radiotherapy for orbital tumours have a higher risk of developing radiation retinopathy if the total dose exceeds $3000 \mathrm{cGy}$. Up to $41 \%$ of patients receiving radiotherapy to the nasopharynx, paranasal sinuses and the nasal cavities are also likely to develop radiation retinopathy. However, radiation of brain tumours carries a relatively small risk.

Radiation retinopathy develops slowly often taking up to eight years or longer to become observable or visually significant. Most microvascular lesions progress slowly and in a significant proportion of patients (about 50\%) sight threatening complications develop. Laser photocoagulation is useful in limiting the degree of macular oedema and containing vasoproliferation. With appropriate management most patients will maintain adequate vision for prolonged periods.

Patients with diabetes and diabetic retinopathy are particularly sensitive to the superimposed insult of ionising radiation and should be closely supervised following treatment.

Better co-operation between the radiotherapist and the ophthalmologist in treatment planning and the development of an after care plan for the patient receiving cephalic radiation will help reduce ocular morbidity.

We would like to thank Dr. G. Lynch, FRCR, DMRT, (late) Consultant Radiotherapist, Northern Ireland Radiotherapy Centre, Belvoir Park Hospital, Belfast and his colleagues for help and advice in setting up this study. We would also like to thank Mrs Margaret Craig, Medical Records Department, Belvoir Park Hospital, Belfast for help in tracing patients and their case notes. We should also like to thank Mrs Rosemary Hepburn for secretarial assistance.

\footnotetext{
References

${ }^{1}$ McFaul, PA and Bedford MA: Ocular complications after therapeutic irradiation. Br J Ophthalmol 1970, 54: 237-47.

${ }^{2}$ Merriam GR, Jr, and Focht EF: A clinical study of
} 
radiation cataract and the relationship to dose. Am J Roentgenol 1957, 77: 759-85.

${ }^{3}$ Merriam GR, Jr, Szechter A, Focht EF: The effects of ionising radiation on the eye. Front Radiation Ther Oncol 1972, 6: 346-85.

${ }^{4}$ Nakissa N, Rubin P, Strohl R, Keys H: Ocular and orbital complications following therapy of paranasal sinus malignancies and review of literature. Cancer 1983, 51: 980-6.

${ }^{5}$ Harris JR and Levene MB: Visual complications following irradiation for pituitary adenomas and craniopharyngiomas. Radiology 1976, 120: 167-71.

${ }^{6}$ Aristazabal S, Caldwell WK, Avila J: The relationship of time dose fractionation factors to complications in the treatment of pituitary tumours by irradiation. Int J Rad Oncol Bio Phys 1977, 2: 667-73.

${ }^{7}$ Baily NA and Noell WK: Relative biologic effectiveness of various qualities of radiation as determined by electroretinograms. Radiat Res 1958, 9: 459.

${ }^{8}$ Thompson GM, Midgal CS, Whittle RJM: Radiation retinopathy following treatment of posterior nasal space carcinoma. $\mathrm{Br} \mathrm{J}$ Ophthalmol 1983, 67: 609-14.

${ }^{9}$ Midena E, Segato T, Piemarocchi S, et al.: Retinopathy following radiation therapy of paranasal sinus and nasopharyngeal carcinoma. Retina 1987, 7: 141-7.

${ }^{10}$ Wara WM, Irvine AR, Neger RE, et al.: Radiation retinopathy. Int J Radiat Oncol Biol Phys 1979, 5: 81-3.

${ }^{11}$ Shukovsky LJ and Fletcher GH: Retinal and optic nerve complications in a high dose irradiation technique of ethmoid sinus and nasal cavity. Radiology 1972, 104: 629-34.

${ }^{12}$ Chan RC and Shukovsky LJ: Effects of irradiation on the eye. Radiology 1976, 120: 673-5.

${ }^{13}$ Bagan SM and Hollenhorst RW: Radiation retinopathy after irradiation of intracranial lesions. $\mathrm{Am}$ J Ophthalmol 1979, 88: 694-7.

${ }^{14}$ Tomsak R and Smith LJ: Radiation retinopathy in a patient with lung carcinoma metastatic to brain. Ann Ophthalmol 1980, 12: 619-22.

${ }^{15}$ Elsas T, Thorud E, Jetne V, Conradi IS: Retinopathy after low dose irradiation for an intracranial tumour of the frontal lobe. Acta Ophthalmol 1988, 66: 65-8.
${ }^{16}$ Brown GC, Shields JA, Sanborn G, et al .: Radiation retinopathy. Ophthalmol 1982, 89: 1494-501.

${ }^{17}$ Bessel EM, Henk JM, Whitelock RAF, Wright JE: Orbital morbidity after radiotherapy of orbital and conjunctival lymphoma. Eye 1987, 1: 90-6.

${ }^{18}$ Elmassri A: Radiation chorioretinopathy. Br J Ophthalmol 1986, 70: 326-9.

${ }^{19}$ Griffin JD and Garnick MB: Eye toxicity of cancer chemotherapy-literature review. Cancer 1981, 48: $1539-49$.

${ }^{20}$ Dhir SP, Joshi AV, Banerjee AK: Radiation retinopathy in diabetes mellitus. Acta Radiol Oncol 1982, 21: 111-13.

${ }^{21}$ Donaldson SS, Bagshaw MA, Kriss JP: Supervoltage orbital radiotherapy for Graves' ophthalmology. J Clin Endocrinol Metab 1973, 37: 276-85.

${ }^{22}$ Brennan MW, Leone CR, Jr, Janaki L: Radiation therapy for Graves' Disease. Am J Ophthalmol 1983, 96: 195-99.

${ }^{23}$ Kinyoun JL, Kalina RE, Brower SA, et al .: Radiation retinopathy after orbital irradiation for Graves' Ophthalmopathy. Arch Ophthalmol 1984, 102: 1473-6.

${ }^{24}$ Mewis L, Tang RA, Salmonsen PC: Radiation retinopathy after safe levels of irradiation. Invest Ophthalmol Vis Sci 1982, 22 (Suppl): 222.

${ }^{25}$ Bogren HG, Franti CE, Wilmarth SS: Normal variations of the position of the eye in the orbit. Ophthalmology 1986, 93: 1072-7.

${ }^{26}$ Noble KG and Kupersmith MJ: Retinal vascular remodelling in radiation retinopathy. $\mathrm{Br} \mathrm{J} \mathrm{Oph}$ thalmol 1984, 68: 475-8.

${ }^{27}$ Chee PHY: Radiation retinopathy. Am J Ophthalmol 1968, 66: 860-5.

${ }^{28}$ Gass JDM: A fluorescein angiographic study of macular dysfunction secondary to retinal vascular disease VI. X-ray irradiation, carotid artery occlusion, collagen vascular disease and iritis. Arch Ophthalmol 1968, 80: 606-17.

${ }^{29}$ Kinyoun JL, Chittum ME, Wells CG: Photocoagulation treatment of radiation retinopathy. $A m \mathrm{~J}$ Ophthalmol 1988, 105: 470-8.

${ }^{30}$ Chaudhuri PR, Austin DJ, Rosenthal AR: Treatment of radiation retinopathy. Br J Ophthalmol 1981, 65: 623-5.

${ }^{31}$ Parsons JT, Fitzgerald CR, Hood CI, et al .: The effects of irradiation on the eye and optic nerve. Int J Radiat Oncol Biol Phys 1983, 9: 609-22. 